\title{
COMPARISON OF DIFFERENT INTERNATIONALLY ACCEPTED REFERENCE STANDARDS TO MEASURE CHILDHOOD ADIPOSITY RATES IN LATVIA
}

\author{
Sarmìte Kupča ${ }^{\star, \star \star}$, Alfrēeds Jānis Sīpols",**, Ilva Daugule*, and Ingrīda Rumba-Rozenfelde* \\ * Faculty of Medicine, University of Latvia, Šarlotes iela 1a, Rīga, LV-1001, LATVIA; \\ sarmite.kupca@gmail.com \\ ** Institute of Experimental and Clinical Medicine, University of Latvia, Ojāra Vācieša iela 4, Rīga, LV-1004, LATVIA
}

Contributed by Ingrīda Rumba-Rozenfelde

\begin{abstract}
Childhood adiposity is increasingly affecting developed and developing countries alike. Body Mass Index (BMI) is a good first approximation of body weight, but interpretation in specific patient populations may be inconsistent. The aim of this study was to compare adiposity rates using three internationally accepted weight reference standards - World Health Organisation (WHO), International Obesity Task Force (IOTF), and US Centers for Disease Control (CDC), plus a local national scale (LV), evaluating 465, 6-to-9-year old school children in Latvia. After obtaining height and weight, BMI was calculated, and the four scales were individually applied by gender and age. Highly significant differences between $L V$ and CDC, LV and IOTF, LV and WHO were found in all age groups $(\mathrm{P}<0.01)$, and between WHO and IOTF reference standards $(\mathrm{P}<0.01)$ in 7- and 8-year olds. We conclude that reference standards should be used with great caution. Reference standards for local ethnic populations are needed to avoid disagreements between scales, as this can lead to incorrect choice of therapy; reliance on any single reference standard may not consider a patient's unique set of circumstances that have resulted in excess weight and information that is vital for a good clinical outcome.
\end{abstract}

Key words: childhood, obesity, reference standards, BMI, Latvia.

\section{INTRODUCTION}

Childhood adiposity is a rapidly increasing problem worldwide, affecting developed and developing countries alike. The consequences of unchecked weight gain among the youth portend even greater national health care expenditures, as these individuals attain adulthood burdened with cardiovascular disease (CVD) and metabolic disorders (Chen et al., 2012; de Onis et al., 2012). Despite advantages in educational level and healthcare infrastructure, economically advanced regions appear to be very susceptible to this trend. For example, as many as $20 \%$ of all children and adolescents in Europe were recently characterised as overweight and almost $7 \%$ were obese, according to the World Health Organisation (Branca, 2007).

The evaluation of this phenomenon demands clear and universally applicable criteria regarding an individual's health status. To this end, anthropometric data are singularly important for a first approximation of a person's state of health. In evaluating a child's whole body development, weight and height need to be measured, and calculations of BMI (Body Mass Index, $\mathrm{kg} / \mathrm{m}^{2}$ ) are then compared to standardised data with reference to age and gender. It is widely recognised that BMI is a more objective measure than weight for height (Mei et al., 2002; Freedman, 2005) in evaluating adiposity and underweight. Moreover, it is easy to interpret, informative and has negligible cost.

Once a child with adiposity has been weighed and measured, his/her BMI needs to be evaluated using age- and gender-appropriate reference standards. Elevated BMI in childhood is strongly associated with increased risk of coronary heart disease in adulthood, as well as increased risk of acute coronary syndrome (Baker et al., 2007; Jensen et al., 2008; Andersen et al., 2010). Elevated low density lipoprotein (LDL) or elevated triglyceride (TG) levels are usually treated pharmacotherapeutically when initial dietary modifications have not resulted in an improved blood lipid profile, and if the child has a high-risk factor, including BMI at or above the $97^{\text {th }}$ percentile. It should be noted that a moderate risk of CVD is already present at the $95^{\text {th }}$ percentile (Anonymous, 2011). Therefore, it is important to evaluate each individual child according to the appropriate growth reference scale to determine whether the child's BMI is at or above the $97^{\text {th }}$ percentile to know whether pharmacotherapy should or should not be initiated.

There are at present three widely used reference standards to evaluate BMI in children and adolescents according to 
age and gender: International Obesity Task Force (IOTF), World Health Organisation (WHO) and United States Center for Disease Control (CDC). In addition, local Latvian growth charts (LV) have been created based on studies that included thousands of children from birth and infancy through adolescence (Krūmina u.c., 2007). With this variety of reference standards available, it is important for physicians to use scales that are appropriate for the evaluation of individual children, because the future management of their assigned therapy depends on precise and accurate evaluation of excess weight. The aim of this study was to compare adiposity rates using three internationally accepted weight reference standards - World Health Organisation (WHO), International Obesity Task Force (IOTF), and US Centers for Disease Control (CDC), plus a local national scale.

\section{MATERIALS AND METHODS}

The study design consisted of interviewing and taking anthropometric measurements of primary school children in the initial grades representing a cross-section of their peers in Latvia. Before the study began, its design was approved by the Scientific Investigation Ethics Commission of the University of Latvia Institute of Experimental and Clinical Medicine.

Following informed consent granted by their parents or legal guardians, 456 children (50.7\% boys) having an average age of $7.5 \pm 1.5$ years participated in the study. Subjects included children attending their neighbourhood primary school in Riga (urban), near the capital (suburban) and in outlying (rural) areas of Latvia. Body height was measured without shoes using a wall-mounted stadiometre to the nearest $0.1 \mathrm{~cm}$. Body weight was measured without shoes, in underwear, using a beam scale measuring a maximum weight of $140 \mathrm{~kg}$ to nearest $0.1 \mathrm{~kg}$. BMI $\left(\mathrm{kg} / \mathrm{m}^{2}\right)$ was calculated for each child and applied individually — using ageand gender-appropriate criteria - according to widely used reference scales created under the auspices of the International Obesity Task Force, the World Health Organization, and the U.S. Centers for Disease Control and Prevention. In addition, a local Latvian reference scale (Krūmina u.c., 2007) was also applied to compare the criteria and cut-off points of the other reference scales, all using the identical data from the study participants.

The International Obesity Task Force (IOTF). In 2000, the IOTF published cut-off points to evaluate the BMI of children, defining childhood obesity and overweight. To define cut-off points, the IOTF included 192727 subjects representing nationally large groups of subjects from Brazil, Great Britain, Hong Kong, The Netherlands, Singapore and the United States. This scale defines three classifications of BMI: obese, overweight and normal weight, each genderand age-appropriate (Cole et al., 2000; Cole et al., 2007).

The World Health Organization (WHO). In 2007, the WHO published revised National Center for Health Statistics (NCHS)/WHO tables from data originally collected in
1977 and released new growth evaluation reference charts. These charts were generated after collecting additional data from six ethnically different countries (Ghana, Oman, the United States, Brazil, India and Norway). A child was deemed obese if his/her BMI was greater than the $97^{\text {th }}$ percentile for that age and gender, and overweight if the BMI was greater that the $85^{\text {th }}$ percentile. Normal weight for children was defined as a BMI greater than the $15^{\text {th }}$ percentile but less than the $85^{\text {th }}$ percentile. If the BMI was less than the $15^{\text {th }}$ percentile, children were classified as underweight (de Onis et al., 2007).

The United States Centre for Disease Control and Prevention (CDC). CDC growth references contain revised data previously used and published in 2002. In the CDC recommendations, children were classified as obese if their BMI was above the $95^{\text {th }}$ percentile and overweight if their BMI was above the $85^{\text {th }}$ percentile. Normal weight was defined for children having a BMI less than the $85^{\text {th }}$ percentile but greater than the $5^{\text {th }}$ percentile. A child was deemed underweight if his/her BMI was less then the $5^{\text {th }}$ percentile for others of that age and gender (Kuczmarski et al., 2002).

The Latvian growth charts $(\mathbf{L V})$. The Latvian growth charts were created following a transverse and semilongitudinal study spanning 1998-2005, which included 8000 subjects from different regions of Latvia. Using the LV charts, a BMI above the $97^{\text {th }}$ percentile was classified as obese, a BMI above the $65^{\text {th }}$ percentile was classified as overweight, and a BMI greater than the $35^{\text {th }}$ percentile and less than the $65^{\text {th }}$ percentile was defined as normal weight. However, a BMI less than the $35^{\text {th }}$ percentile was classified as underweight (Krumina, 2007).

Statistical analysis. Descriptive statistics were calculated for all anthropometric parameters. Comparisons of category designations (normal, overweight, obese) were accomplished by means of chi--squared analysis across the reference scales. We considered results to be statistically significant if the $P$ value was less than $0.05(P<0.05)$, highly significant if the $P$ value was less than $0.01(P<0.01)$, and very highly significant if the $P$ value was less than 0.001 $(P<0.001)$.

\section{RESULTS}

The study group included 456 (49.3\% girls) children, mean age $7.53 \pm 0.65$ years, mean weight $28.64 \pm 5.47 \mathrm{~kg}$, mean height $1.31 \pm 0.07 \mathrm{~m}$. All children were evaluated by CDC, IOTF, WHO and LV reference standards.

To characterize the study group, Table 1 displays the frequency distribution of weight classifications in percentages at specific ages for all subjects (both genders) according to CDC, IOTF, WHO and LV reference standards.

Table 2 shows the subjects' BMI distribution by their weight classification, according to each of the reference standards. 
PREVALENCE (\%) OF OBESITY, OVERWEIGHT, NORMAL WEIGHT AND UNDERWEIGHT IN CHILDREN AGED 6 TO 9 YEARS OLD, ASSESSED USING INTERNATIONAL AND LOCAL BMI REFERENCE STANDARDS

\begin{tabular}{clccccc}
\hline Age & & CDC & IOTF & WHO & LV \\
\hline 6 years & Obese & 15.4 & 7.70 & 15.7 & 11.5 \\
& Overweight & 3.80 & 11.5 & 7.70 & 26.9 \\
& Normal weight & 65.4 & 80.8 & 61.3 & 15.4 \\
& Underweight & 15.4 & & 15.3 & 46.2 \\
\hline 7 years & Obese & 5.36 & 2.40 & 5.90 & 4.40 \\
& Overweight & 15.6 & 12.7 & 19.0 & 37.5 \\
& Normal weight & 73.2 & 84.9 & 67.3 & 25.5 \\
& Underweight & 5.84 & & 7.80 & 32.6 \\
\hline \multirow{2}{*}{8 years } & Obese & 10.6 & 5.20 & 16.8 & 12.4 \\
& Overweight & 17.2 & 20.6 & 17.2 & 41.7 \\
& Normal weight & 70.3 & 74.2 & 60.2 & 19.6 \\
& Underweight & 1.90 & & 5.80 & 26.3 \\
\hline 9 years & Obese & 12.5 & 0.00 & 12.5 & 12.5 \\
& Overweight & 0.00 & 18.8 & 0.00 & 25.0 \\
& Normal weight & 75.0 & 81.2 & 75.0 & 25.0 \\
& Underweight & 12.5 & & 12.5 & 37.5
\end{tabular}

United States Centre for Disease Control and Prevention (CDC), International Obesity Task Force (IOTF), World Health Organization (WHO), Latvian growth charts (LV)

Table 2

BODY MASS INDEX (KG/M $\left.{ }^{2}\right)$ OF THE ENTIRE STUDY GROUP $(\mathrm{MEAN} \pm \mathrm{SD})$ ACCORDING TO VARIOUS REFERENCE STANDARDS

\begin{tabular}{l|c|c|c}
\hline & BMI obese & BMI overweight & BMI normal weight \\
\hline CDC & $22.0 \pm 1.9$ & $19.0 \pm 1.0$ & $15.9 \pm 1.2$ \\
IOTF & $23.4 \pm 1.9$ & $19.8 \pm 1.1$ & $15.7 \pm 1.5$ \\
WHO & $21.6 \pm 1.8$ & $18.5 \pm 0.8$ & $15.7 \pm 1.1$ \\
LV & $22.1 \pm 1.8$ & $17.9 \pm 1.1$ & $15.9 \pm 0.4$
\end{tabular}

For designations see Table 1.

Table 3A displays the statistical comparisons between the different reference scales in all subjects 6 years of age. Highly statistically significant differences between Latvian growth standards and CDC, WHO and IOTF reference standards were found $(P<0.01)$. However, no significant differences were revealed when comparing CDC, WHO and IOTF growth standards with each other.

Differences in weight classification percentages between the LV and international reference scales among the 7 -years-olds (Table 3B) were even greater than those seen in the 6-year-olds, with very highly significant differences $(P<0.0001)$ observed in comparisons with $\mathrm{CDC}$, WHO and IOTF growth standards. Moreover, significant differences were found in comparing IOTF with WHO $(P<$ $0.01)$, and IOTF with CDC $(P<0.04)$ growth standards. No differences were detected when comparing WHO and CDC reference scales at this age.
STATISTICAL SIGNIFICANCE (P) OF DIFFERENCES BETWEEN VARIOUS REFERENCE STANDARDS

A. For all 6-year-olds

\begin{tabular}{l|c|c|c}
\hline & CDC & IOTF & WHO \\
\hline IOTF & $P=0.41$ & & \\
WHO & $P=0.95$ & $P=0.36$ & \\
LV & $P=0.001^{*}$ & $P=0.01^{*}$ & $P=0.01^{*}$
\end{tabular}

B. For all 7-year-olds

\begin{tabular}{l|c|c|c}
\hline & CDC & IOTF & WHO \\
\hline IOTF & $P=0.04^{*}$ & \\
WHO & $P=0.61$ & $P=0.01^{*}$ \\
LV & $P<0.0001^{*}$ & $P<0.0001^{*}$ & $P<0.0001^{*}$ \\
\multicolumn{5}{c}{} \\
C. For all 8-year-olds \\
\hline \multicolumn{4}{c}{ IOTF } \\
\hline IOTF & $P=0.11$ & WHO \\
WHO & $P=0.04^{*}$ & $P=0.001^{*}$ & \\
LV & $P<0.0001^{*}$ & $P<0.0001^{*}$ & $P<0.0001^{*}$
\end{tabular}

For designations see Table 1. Significant differences denoted by *.

Table $3 \mathrm{C}$ represents data comparing weight classification percentages of reference scales in 8-year-old children in our study group. The results revealed no differences in comparing IOTF and CDC reference standards, but significant differences were detected comparing WHO with CDC $(P<$ 0.04), WHO with IOTF $(P<0.001)$, and LV with CDC, IOTF and WHO (all at $P<0.001$ ) reference standards.

\section{DISCUSSION}

The present study was designed to allow direct comparison of different internationally accepted reference standards currently used to assess the extent of childhood adiposity in Latvia. We selected common, widely used scales and analysed a group of 456 randomly selected Latvian school children of various body weight according to the criteria and cut-off points established within these reference scales. Although it is unsurprising, and in fact mathematically predictable, that variations would be detected between the reference standards in the same group of subjects, the extent of the differences observed was entirely unanticipated.

A number of factors were considered in the context of interpreting these results. It should be noted that while all participants in this study were volunteers, consenting to participate without compensation (following parental or legal guardian informed consent), there were potential participants that, or their parents, declined participation based on lack of compensation, thereby decreasing the number of participants. In addition, a substantial proportion of potential subjects declining participation were clearly obese (Kupča, personal observation). Therefore, a large number of children that eventually participated as study subjects were 
more slender and healthier than the potential pool of subjects, thus skewing the weight classification percentages. These factors alone preclude any claim of the 456 subjects representing a precise cross-section of Latvian children at those ages, although this in no way diminishes the analysis of reference scales applied to identical subjects. Another factor was the possibility of precocious puberty among some of the participants, although this likelihood was discounted, as none of the included children was observed to have secondary sexual characteristics.

Previous studies reported significant differences between international reference standards in various populations (Shields and Tremblay, 2010; Fetuga et al., 2011; Twells and Newhook, 2011; Mushtaq et al., 2012), and comparison of international reference standards with local reference standard also has found significant differences (Cerrillo et al., 2012).

Our results revealed differences in assessing BMI in obese children and in overweight children using different assessment charts - CDC, IOTF, WHO, LV reference standards. Assessing all children by CDC, obese children had mean BMI $\left( \pm\right.$ SD) of $22.0 \pm 1.9 \mathrm{~kg} / \mathrm{m}^{2}$, but by IOTF $23.4 \pm 1.9$ $\mathrm{kg} / \mathrm{m}^{2}$, and by WHO $21.6 \pm 1.8 \mathrm{~kg} / \mathrm{m}^{2}$; by LV assessment charts obese children had mean BMI $22.1 \pm 1.8 \mathrm{~kg} / \mathrm{m}^{2}$ (Table 2). This indicates the differences between evaluation using different reference standards, as the BMI of defined obese children clearly differed.

Evaluating a variety of ethnic groups with reference standards based on different populations can be controversial scientifically as well as politically. Body constitution differs among varying ethnicities (Ellis, 1997; Ellis et al., 1997; Duncan, et al., 2009), and it is important to evaluate a child's body form by growth charts that are adapted to and congruent with local ethnic populations. Reference standards need to be as demographically objective as possible, appropriate not only in terms of age and gender, but also of ethnic background, to impartially evaluate a child's constitution in order to form an appropriate diagnosis in the support of therapeutic intervention, if necessary. That leads us to suggest that ethnic background is an important variable when creating reference standards regarding body constitution, and the significant differences observed in our study between the reference scales measuring an identical group of subjects are likely due to the specific population upon which each of the reference standards were based. There are studies that conclude the need of ethnic specific growth charts (Bayat et al., 2012).

The Latvian population is quite homogenous from an ethnic standpoint, and it could well be inappropriate to determine a child's BMI using growth references that are compiled by using, for example, Japanese or African-American children. Most of Latvia's citizens are of Europoid (Caucasian) ethnic origins, and when BMI is assessed using reference standards created by including large representations of IndoAryan (Southeast Asian) ethnicities, it can lead to incorrect evaluation, hence diagnostic error.
The Endocrine Society has included the recommendation in their Clinical Guidelines that only obese children should be treated pharmacotherapeutically, meaning children with a BMI of at least at the $95^{\text {th }}$ percentile of age and gender. These same guidelines state that overweight children not reaching the obese category should avoid pharmacotherapy. The Endocrine Society further recommends using the CDC reference standards. Examining the weight categories of all children at seven years of age in our study, the CDC reference standards define 15.6 percent of these subjects as overweight, whereas assessing the same age group (i.e., identical data) using LV reference standards yields a percentage of only 37.5 - more than twice the frequency of overweight as with the CDC reference standards (Kuczmarski et al., 2002). The distribution by ethnicity of children comprising the CDC standards was $62 \%$ Non-Hispanic White, $15 \%$ Non-Hispanic Black, 18\% Hispanic, 4\% Asian/Pacific Islander and 1\% American Indian/Alaska Native (Anonymous, 2001). In contrast, the Latvian population with an overwhelming majority of Caucasian ethnicity and having negligible Hispanic or African-American representation, is very homogenous, and the results of our study support the contention that reference standards in this case should also be homogenous to reach the goal of objective assessment.

Nevertheless, internationally accepted growth references are essential in multi-national studies where populations of children having various ethnic backgrounds are compared to analyse trends of childhood obesity and body constitution. With increasing globalisation, it is imperative to estimate rates of obesity in children in different regions of the world, and as many regions are becoming more ethnically heterogeneous, standards such as the CDC, IOTF and WHO charts are certainly appropriate. However, in countries or regions that are ethnically homogeneous, significant differences may well be found in weight classification frequencies between the CDC, IOTF and WHO reference standards and locally generated scales, as was the case in our study of Latvian schoolchildren.

The importance of these distinctions cannot be overstated. Any reference standard should be used with great caution to avoid disagreements between scales that form the basis of an incorrect choice of therapy. Moreover, standard scales should be as objective as possible, with clear clinical implications of a patient's state of health. However, it must always be remembered that patients present with various apparent as well as not-so-obvious antecedents of obesity, and a clinician should first and foremost look at the patient as an individual, with his/her own genetic and alimentary background. Therefore, we would caution that strict overreliance on any reference standard on a measure as complicated as body weight means discounting a patient's individuality and unique set of circumstances that have resulted in the excess weight, information that is vital for a good clinical outcome.

Finally, as mentioned above, studies of this nature cannot easily overcome problems in methods and study protocol. Ethical guidelines ensuring complete autonomy of subjects 
rightfully and appropriately exclude forced participation and compliance with investigator requests. This self-selection of subjects, however, means that true cross-sectional studies are beset with an important shortcoming: subjects from a random pool do not reflect the general population, especially when body weight is the independent variable under investigation. Nevertheless, the focus of our study was not on the frequency of obesity in Latvian schoolchildren, but rather on the various reference standards and their applicability to specific populations. Our results unambiguously indicate that the axiom "one size does not fit all" in reference to childhood obesity assessment standards certainly holds true, and that the most useful scales in assessing overweight and obesity and their eventual treatment strategies are those that are locally generated, consistent with the ethnic demographics of the population being studied.

In conclusion, statistically significant differences between Latvian reference standards and internationally accepted reference standards exist in the assessment of overweight and obesity in children $(P<0.01)$. We encourage clinicians to support the creation of individual reference standards based on local ethnic populations, resulting in more objective assessment, more accurate diagnoses and selection of appropriate therapeutic strategies, to more successfully combat overweight and obesity.

\section{ACKNOWLEDGEMENTS}

This study was supported by the Latvian National Research Programme 2010-2013, "Development of new prevention, treatment, diagnostics means and practices and biomedicine technologies for improvement of public health".

Sarmìte Kupča has been supported by the European Social Fund within the project "Support for Doctoral Studies at the University of Latvia”.

\section{REFERENCES}

Andersen, L. G., Angquist, L., Eriksson, J. G., Forsen, T., Gamborg, M., Osmond, C., Baker, J. L., Sorensen, T. I. (2010). Birth weight, childhood body mass index and risk of coronary heart disease in adults: Combined historical cohort studies. PLoS One, 5 (11), e14126.

http://www.ncbi.nlm.nih.gov/pubmed/21124730.

Anoymous (2011). Expert Panel on Integrated Guidelines for Cardiovascular Health and Risk Reduction in Children and Adolescents: Summary Report.

https://www.nhlbi.nih.gov/guidelines/cvd_ped/peds_guidelines_sum.pdf

Baker, J. L., Olsen, L. W., Sorensen, T. I. (2007). Childhood body-mass index and the risk of coronary heart disease in adulthood. New Engl. J. Med., 357 (23), 2329-2337.

Bayat, P. D., Khazaei, M., Ghorbani, R., Ayubian, M., Sohouli, P., Ghanbari, A. (2012). Growth pattern in 7-12 years old Arak children (central Iran) in comparison with other ethnic subgroups of Iran. Ital. J. Anat. Embryol., 117 (1), $1-7$

Branca, F., Nikogosian, H., Lobstein, T. (2007). The Challenge of Obesity in the Who European Region and the Strategies for Response. World Health Organization.
Cerrillo, I., Fernandez-Pachon, M. S., Ortega Mde, L., Valero, E., Martin, F. M., Jauregui-Lobera, I., Berna, G. (2012). Two methods to determine the prevalence of overweight and obesity in 8-9 year-old-children in Seville, Spain. Nutr. Hosp., 27 (2), 463-468.

Chen, F., Wang, Y., Shan, X., Cheng, H., Hou, D., Zhao, X., Wang, T., Zhao, D., Mi, J. (2012). Association between childhood obesity and metabolic syndrome: Evidence from a large sample of Chinese children and adolescents. PLoS One, 7 (10), e47380.

Cole, T. J., Flegal, K. M., Nicholls, D., Jackson, A. A. (2007). Body mass index cut offs to define thinness in children and adolescents: International survey. BMJ, 335 (7612), 194.

Cole, T. J, Bellizzi, M. C, Flegal, K. M, Dietz, W. H. (2000). Establishing a standard definition for child overweight and obesity worldwide: International survey. BMJ, 320 (7244), 1240.

de Onis, M., Martinez-Costa, C., Nunez, F., Nguefack-Tsague, G., Montal, A., Brines, J. (2012). Association between WHO cut-offs for childhood overweight and obesity and cardiometabolic risk. Public Health Nutr, 16 (4), 1-6.

de Onis, M., Onyango, A. W., Borghi, E., Siyam, A., Nishida, C., Siekmann, J. (2007). Development of a WHO growth reference for school-aged children and adolescents. Bull World Health Organ, 85 (9), 660-667.

Duncan, J. S., Duncan, E. K., Schofield, G. (2009). Accuracy of body mass index (BMI) thresholds for predicting excess body fat in girls from five ethnicities. Asia Pac. J. Clin. Nutr., 18 (3), 404-411.

Ellis, K. J. (1997). Body composition of a young, multiethnic, male population. Amer. J. Clin. Nutr., 66 (6), 1323-1331.

Ellis, K. J., Abrams, S. A., Wong, W. W. (1997). Body composition of a young, multiethnic female population. Amer. J. Clin. Nutr., 65 (3), 724-731.

Fetuga, M. B., Ogunlesi, T. A., Adekanmbi, A. F., Alabi, A. D. (2011). Growth pattern of schoolchildren in Sagamu, Nigeria using the CDC standards and 2007 WHO standards. Indian Pediatr, 48 (7), 523-528.

Freedman, D. S, Wang, J., Maynard, L. M, Thornton, J. C, Mei, Z., Pierson, R. N., Dietz, W. H., Horlick, M. (2005). Relation of BMI to fat and fat-free mass among children and adolescents. Int. J. Obes. (Lond), 29, 1-8.

Jensen, M. K., Chiuve, S. E., Rimm, E. B., Dethlefsen, C., Tjonneland, A., Joensen, A. M., Overvad, K. (2008). Obesity, behavioral lifestyle factors, and risk of acute coronary events. Circulation, 117 (24), 3062-3069.

Krūmiņa, Dz., Kokare, I., Biķis, E. (2007). Latvijas bērnu fiziskās attīstības novērtēšana [Assesment of Physical Development in Latvian Children]. Rīga: Medicīnas apgāds. 23 lpp.

Kuczmarski, R. J., Ogden, C. L., Guo, S. S., Grummer-Strawn, L. M., Flegal, K. M., Mei, Z., Curtin, L. R., Roche, A. F., Johnson, C. L. (2002). 2000 CDC Growth Charts for the United States: Methods and Development. National Center for Health Statistics. Vital Health Stat., 11 (246).

Mei, Z., Grummer-Strawn, L. M., Pietrobelli, A., Goulding, A., Goran, M. I., Dietz, W. H. (2002). Validity of body mass index compared with other body-composition screening indexes for the assessment of body fatness in children and adolescents. Amer. J. Clin. Nutr., 75 (6), 978-985.

Mushtaq, M. U., Gull, S. M., Komal, A., Hussain, M., Khurshid, U., Shahid, U., Akram, J. (2012). Height, weight and BMI percentiles and nutritional status relative to the international growth references among Pakistani school-aged children. BMC Pediatrics, 12 (1), 31.

Shields, M., Tremblay, M. S. (2010). Canadian childhood obesity estimates based on WHO, IOTF and CDC cut-points. Int. J. Pediatr. Obes., 5 (3), 265-273.

Smelser, N., Wilson, W. J., Mitchell, F. (eds.). (2001). America Becoming: Racial Trends and Their Consequences, Volume II. Washington, D. C.: The National Academies Press. 480 pp.

Twells, L. K., Newhook, L. A. (2011). Obesity prevalence estimates in a Canadian regional population of preschool children using variant growth references. BMC Pediatrics, 11, 21. 


\section{DAŽĀDU STARPTAUTISKI ATZĪTU ADIPOZITĀTES IZVĒRTĒŠANAS SKALU SALĪDZINĀJUMS BĒRNIEM LATVIJĀ}

Bērnu aptaukošanās izplatība strauji pieaug gan attīstītās, gan jaunattīstības valstīs. K,ermeņa masas indekss (ĶMI) tiek izmantots barojuma izvērtēšanā, tomēr tā interpretācija dažādās pacientu populācijās var būt maldinoša. Pētījuma mērḳis bija salīdzināt aptaukošanās pakāpes, lietojot trīs starptautiski atzītas izvērtēšanas skalas - Pasaules veselības organizācijas (World Health Organization (WHO)), Starptautiskās aptaukošanās darba grupas (International Obesity Task Force (IOTF)), ASV slimības kontroles novēršanas centra (US Centers for Disease Control (CDC)), kā arī Latvijas izvērtēšanas skalas (LV). Tika izvērtēti 465 Latvijā dzīvojoši bērni, 6 līdz 9 gadus veci. Bērni tika nosvērti un izmērīiti, tika aprēḳināts ĶMI, un viṇi tika individuāli izvērtēti, ṇemot vērā bērna dzimumu un vecumu, pēc visām četrām izvērtēšanas skalām. Statistiski ticamas atškirības bija starp LV un CDC, LV un IOTF, LV un WHO $(P<0.01)$ visās vecuma grupās, savukārt, salīdzinot WHO un IOTF $(P<0.01)$, statistiski ticamas atšķirības bija 7 un 8 gadu vecuma grupā. Mēs secinām, ka izvērtēšanas skalas būtu jālieto ar lielu piesardzību, vēlams, ņemot vērā lokālās etniskās populācijās veidotas skalas, lai izvairītos no nesaskaņām starp skalām, jo tas varētu būt par pamatu nepareizas terapijas izvēlē. Izvērtējot bērnu, jāṇem vērā bērna individualitāte un apstākḷi, kuri veicinājuši liekāa svara attīstīšanos — šì informācija ir būtiska labākam klīniskam rezultātam. 